\title{
Relationship between blood levels of heavy metals and lung function based on the Korean National Health and Nutrition Examination Survey IV-V
}

This article was published in the following Dove Press journal:

International Journal of COPD

6 August 2015

Number of times this article has been viewed

\author{
Ah Young Leem \\ Se Kyu Kim \\ Joon Chang \\ Young Ae Kang \\ Young Sam Kim \\ Moo Suk Park \\ Song Yee Kim \\ Eun Young Kim \\ Kyung Soo Chung \\ ji Ye Jung
}

Division of Pulmonology, Department of Internal Medicine, Institute of Chest Disease, Severance Hospital, Yonsei University College of Medicine, Seoul, Republic of Korea
Correspondence: ji Ye Jung

Division of Pulmonology, Department of Internal Medicine, Institute of Chest Disease, Severance Hospital, Yonsei University College of Medicine, 50-I

Yonsei-ro, Seodaemun-gu, Seoul I20-752, Republic of Korea

Tel +82 I0 3I4I 2576

Fax +82 23936884

Email stopyes@yuhs.ac
Background: Heavy metal exposure may contribute to inflammation in the lungs via increased oxidative stress, resulting in tissue destruction and obstructive lung function (OLF). In this study, we evaluated the relationship between lead and cadmium levels in blood, and lung function in the Korean population.

Methods: Pooled cross-sectional data from 5,972 subjects who participated in the Korean National Health and Nutrition Examination Survey 2008-2012 were used for this study. OLF was defined as forced expiratory volume in 1 second/forced vital capacity $\left(\mathrm{FEV}_{1} / \mathrm{FVC}\right)<0.7$. Graphite-furnace atomic absorption spectrometry was used to measure levels of lead and cadmium in blood.

Results: Adjusted means for age, sex, body mass index, and smoking status in blood lead and cadmium levels were increased with age and were higher in men and current smokers. The $\mathrm{FEV}_{1} / \mathrm{FVC}$ ratio was lower in the highest quartile group of lead $(78.4 \% \mathrm{vs} 79.0 \% ; P=0.025)$ and cadmium $(78.3 \%$ vs $79.2 \% ; P<0.001)$ concentrations, compared with those in the lowest quartile groups. Multiple linear regression demonstrated an inverse relationship between the $\mathrm{FEV}_{1} / \mathrm{FVC}$ ratio and concentrations of lead (estimated $-0.002 ; P=0.007$ ) and cadmium (estimated $-0.005 ; P=0.001)$. Of the 5,972 subjects, $674(11.3 \%)$ were classified into the OLF group. Among current smokers, the risk of OLF was higher in subjects in the highest quartile group of cadmium concentration than in those in the lowest quartile group (odds ratio 1.94; 95\% confidence interval 1.06-3.57).

Conclusion: We demonstrated a significant association between the $\mathrm{FEV}_{1} / \mathrm{FVC}$ ratio and blood concentrations of lead and cadmium in the Korean population. The risk for OLF was elevated with increasing concentrations of cadmium among current smokers.

Keywords: lead, cadmium, pulmonary function, obstructive lung disease

\section{Introduction}

COPD is an important cause of morbidity and mortality worldwide. Although the most critical risk factor for development of COPD is cigarette smoking, $20 \%-30 \%$ of COPD patients have never smoked..$^{1-3}$ Occupational exposures and air pollution have been associated with development and progression of COPD. ${ }^{4,5}$ Inhalation of airborne pollutants, including oxidant gases such as ozone, nitrogen dioxide, or particulate air pollution, may lead to activation of pulmonary inflammatory processes and lung damage. ${ }^{6}$

Heavy metal exposure may also contribute to increased oxidative stress, disruption of barrier mechanisms, and impaired DNA repair, resulting in inflammation and tissue destruction in the lungs, manifesting clinically as obstructive lung disease. ${ }^{6}$ Only a few observational studies have demonstrated the association between pulmonary disease 
and heavy metal exposure (including lead and cadmium). ${ }^{7-9}$ Recently, a study of a large sample of the US population found a significant relationship between obstructive lung disease and concentrations of cadmium and lead in the blood. ${ }^{10}$ It also demonstrated a dose-dependent inverse association between forced expiratory volume in 1 second $\left(\mathrm{FEV}_{1}\right) \%$ predicted and serum heavy lead and cadmium levels. ${ }^{10}$

Lead and cadmium can enter the body through the various routes of ingestion, inhalation, and skin absorption. . $^{8,911,12}$ In previous studies of the Korean population, the systemic effects of lead and cadmium on renal function and diabetes were reported. ${ }^{13,14}$ Lead and cadmium levels in the blood were associated with reduced epidermal growth factor receptor, but were not associated with prevalence of diabetes in the general Korean population. However, their effect on the lung has not been evaluated in the Korean population.

The aim of this study was to assess the association between lead and cadmium concentrations in the blood and lung function in a large representative sample of the Korean population.

\section{Methods}

\section{Study populations}

This cross-sectional study analyzed pooled data during 2 years (2008-2009) of the Korean National Health and Nutrition Examination Surveys (KNHANES) IV (2007-2009) and the 3 years of KNHANES V (2010-2012). KNHANES is an ongoing cross-sectional survey of the civilian, noninstitutionalized Korean population. ${ }^{15}$ The methodology of the survey has been described previously. ${ }^{3}$ A multistage, stratified, probability sampling method was used, and households for sampling units were selected based on age, sex, and geographical area.

Participants were informed that their household had been randomly selected to participate in this survey performed by the Korean Centers for Disease Control and Prevention. They were given the right to refuse, and all participants signed an informed consent form. The survey comprised a health interview survey, a nutrition survey, and a health examination survey. Data were collected by household interviews and by direct standardized physical examinations and fasting blood sampling conducted in mobile health examination centers. Spirometry was performed by specially trained technicians, using the same type of dry rolling seal spirometer (model 2130, Sensormedics Corporation, Torba Linda, CA, USA) for all subjects. The electronically generated spirometric data were transferred via the Internet to the review center.
Two trained nurses reviewed the test results and provided quality control feedback to the technicians. Among 44,433 subjects whom participated in the survey between 2008 and 2012, we identified 5,972 subjects aged $\geq 20$ years who completed spirometry according to the American Thoracic Society guidelines and whose lead and cadmium levels in the blood were measured. ${ }^{16}$ The Korean Centers for Disease Control and Prevention obtained written and informed consent from all participants, and the institutional review board at Severance Hospital approved the study protocol (4-2013-0803).

\section{Definitions}

Cigarette smoking status was categorized according to questionnaire items, including "Have you smoked at least 100 cigarettes in your entire life?" and "Are you currently smoking?". Current smokers were defined by self-reported active smoking. All self-reported non-active smokers were classified as former smokers (smoked at least 100 cigarettes in their entire life) or never smokers (smoked less than 100 cigarettes in their entire life) based on survey question responses. Ever smokers included current and former smokers. Obstructive lung function (OLF) was defined as pre-bronchodilator $\mathrm{FEV}_{1} /$ forced vital capacity $(\mathrm{FVC})<0.7 .{ }^{17}$

\section{Measurement of lead and cadmium in whole blood}

Blood samples were collected in fasting state during the surveys with prior agreement. Graphite-furnace atomic absorption spectrometry with Zeeman background correction (Analyst 600; Perkin Elmer, Finland) was used to measure lead and cadmium in blood. All blood metal analyses were performed at the Neodin Medical Institute, a laboratory certified by the Korean Ministry of Health and Welfare.

\section{Classification of subjects}

Subjects were categorized into quartiles for each heavy metal as the 25 th percentile (group 1), the 50th percentile (group 2), the 75th percentile (group 3), and the 100th percentile (group 4).

\section{Statistical analysis}

Categorical variables were analyzed using chi-square tests and continuous variables were analyzed using a $t$-test between non-OLF and OLF groups. The blood levels of lead and cadmium were log-transformed because the distribution of lead and cadmium levels was likely skewed in the rightward direction. Analysis of covariance was used to estimate the 
adjusted means of continuous variables (ie, blood lead and cadmium levels, $\mathrm{FEV}_{1}, \mathrm{FVC}$, and $\mathrm{FEV}_{1} / \mathrm{FVC}$ ratio), with independent variables (ie, age, sex, body mass index [BMI], and smoking status). To compare the adjusted means for blood lead and cadmium levels, adjusted factors include age, sex, BMI, and smoking status. To compare the adjusted means of the $\mathrm{FEV}_{1}, \mathrm{FVC}$, and $\mathrm{FEV}_{1} / \mathrm{FVC}$ ratio, blood lead and cadmium levels were also considered respectively. Multivariate linear regression adjusted for age, sex, BMI, and smoking status was performed to evaluate the effect of blood lead and cadmium levels on lung function. The prevalence of OLF was calculated in the quartile groups using multivariate logistic regression with adjustment for age, sex, and BMI. The statistical analysis was performed using SAS Enterprise Guide version 5.1.

\section{Results}

\section{Adjusted means in blood lead and cadmium levels by age, sex, BMI, and smoking status}

Table 1 displays the adjusted mean blood lead and cadmium concentrations for the main covariates, including age, sex, BMI, and smoking. The blood lead level increased with age until 60 years, was higher in men than in women (2.92 $\mu \mathrm{g} / \mathrm{dL}$ vs $2.33 \mu \mathrm{g} / \mathrm{dL} ; P<0.001)$, and was higher in current smokers than in former or never smokers $(2.93 \mu \mathrm{g} / \mathrm{dL}$ vs $2.66 \mu \mathrm{g} / \mathrm{dL}$ and $2.49 \mu \mathrm{g} / \mathrm{dL} ; P<0.001)$. The blood cadmium level increased with age until 60 years, was higher in women than in men $(0.96 \mu \mathrm{g} / \mathrm{dL}$ vs $1.56 \mu \mathrm{g} / \mathrm{dL} ; P<0.001)$, and was higher in current smokers than in former or never smokers $(1.68 \mu \mathrm{g} / \mathrm{dL}$ vs $1.17 \mu \mathrm{g} /$ $\mathrm{dL}$ and $1.09 \mu \mathrm{g} / \mathrm{dL} ; P<0.001)$.

\section{Lung function corresponding to blood lead and cadmium levels adjusted by age, sex, BMI, and smoking}

Table 2 demonstrates the mean for $\mathrm{FEV}_{1}, \mathrm{FVC}$, and $\mathrm{FEV}_{1} /$ FVC ratio by quartile of blood lead and cadmium levels after adjusting for age, sex, BMI, and smoking status. The means for $\mathrm{FEV}_{1}, \mathrm{FVC}$, and $\mathrm{FEV}_{1} / \mathrm{FVC}$ ratio according to stratification of age, sex, BMI, and smoking status are presented in Tables S1 and S2. FEV 1 and FVC was lowest in the lowest quartile (group 1) of lead concentration $(\leq 1.85 \mu \mathrm{g} / \mathrm{L}$ ) compared with the other three quartile groups, and the

Table I Mean and mean difference in blood lead and cadmium concentrations for the main covariates, including age, sex, BMI, and smoking status

\begin{tabular}{|c|c|c|c|c|c|c|c|}
\hline \multirow[t]{2}{*}{ Variable } & \multirow[t]{2}{*}{$\mathbf{n}$} & \multicolumn{2}{|c|}{ Blood lead level } & \multirow[t]{2}{*}{$P$-value } & \multicolumn{2}{|c|}{ Blood cadmium level } & \multirow[t]{2}{*}{$P$-value } \\
\hline & & Mean (SE) & Mean difference (SE) & & Mean (SE) & Mean difference (SE) & \\
\hline \multicolumn{8}{|l|}{$\overline{\text { Age, years** }}$} \\
\hline$\leq 41$ & $\mathrm{I}, 400$ & $2.28(0.03)$ & Ref & & $0.93(0.02)$ & Ref & \\
\hline $42-50$ & $\mathrm{I}, 447$ & $2.54(0.03)$ & $0.25(0.05)$ & $<0.001$ & $1.27(0.02)$ & $0.34(0.02)$ & $<0.001$ \\
\hline $51-59$ & I,552 & $2.86(0.03)$ & $0.57(0.04)$ & $<0.001$ & $1.40(0.02)$ & $0.47(0.02)$ & $<0.001$ \\
\hline$\geq 60$ & 1,516 & $2.8 \mathrm{I}(0.03)$ & $0.53(0.05)$ & $<0.001$ & $1.39(0.02)$ & $0.46(0.02)$ & $<0.001$ \\
\hline$P$-value for Wald $F$ statistic & & & $<0.001$ & & & $<0.001$ & \\
\hline \multicolumn{8}{|l|}{ Sex } \\
\hline Male & 3,018 & $2.92(0.03)$ & Ref & & $0.96(0.01)$ & Ref & \\
\hline Female & 2,897 & $2.33(0.03)$ & $-0.59(0.04)$ & $<0.001$ & $1.56(0.01)$ & $0.60(0.02)$ & $<0.001$ \\
\hline$P$-value for Wald $F$ statistic & & & $<0.001$ & & & $<0.001$ & \\
\hline \multicolumn{8}{|l|}{$\mathrm{BMI}, \mathrm{kg} / \mathrm{m}^{2 * *}$} \\
\hline$\leq 22.06$ & $\mathrm{I}, 487$ & $2.66(0.03)$ & Ref & & $1.23(0.02)$ & $0.01(0.02)$ & \\
\hline $22.07-24.02$ & $|, 48|$ & $2.60(0.03)$ & $-0.06(0.04)$ & 0.180 & $1.24(0.02)$ & $0.01(0.02)$ & 0.678 \\
\hline $24.03-26.05$ & $\mathrm{I}, 475$ & $2.63(0.03)$ & $-0.03(0.04)$ & 0.443 & $1.27(0.02)$ & $0.04(0.02)$ & 0.055 \\
\hline$\geq 26.06$ & $\mathrm{I}, 480$ & $2.64(0.03)$ & $-0.02(0.04)$ & 0.654 & $1.26(0.02)$ & $0.03(0.02)$ & 0.182 \\
\hline$P$-value for Wald $F$ statistic & & & 0.592 & & & 0.209 & \\
\hline \multicolumn{8}{|l|}{ Smoking } \\
\hline Current & $\mathrm{I}, 438$ & $2.93(0.04)$ & Ref & & $1.68(0.02)$ & Ref & \\
\hline Former & 1,225 & $2.66(0.04)$ & $-0.27(0.05)$ & $<0.001$ & $1.17(0.02)$ & $-0.5 \mathrm{I}(0.03)$ & $<0.001$ \\
\hline Never & 3,252 & $2.49(0.03)$ & $-0.44(0.05)$ & $<0.001$ & $1.09(0.01)$ & $-0.58(0.03)$ & $<0.001$ \\
\hline$P$-value for $W$ ald $F$ statistic & & & $<0.001$ & & & $<0.001$ & \\
\hline
\end{tabular}

Notes: Data were adjusted for all variables other than the main covariates, and are presented as the adjusted mean (SE) and mean difference (SE) unless otherwise indicated; **subjects were categorized into four groups for age and BMI as the 25th percentile, the 50th percentile, the 75th percentile, and the 100th percentile.

Abbreviations: BMI, body mass index; SE, standard error; Ref, reference. 


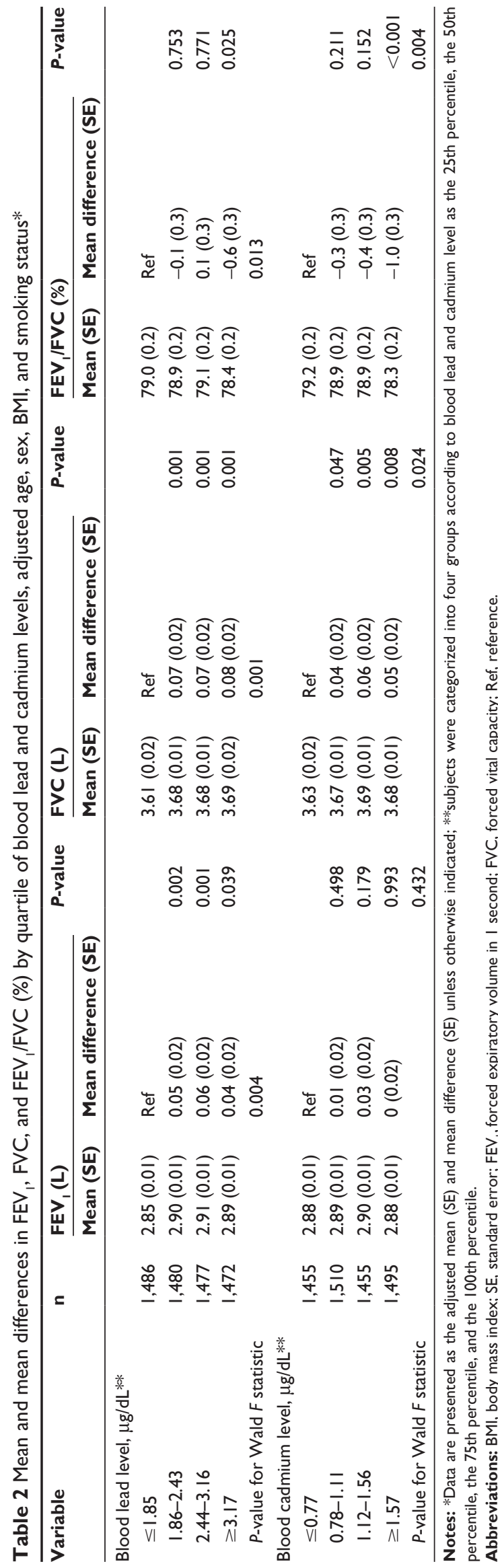

dose-response relationship was not significant. However, the $\mathrm{FEV}_{1} / \mathrm{FVC}$ ratio was lower in the highest quartile of lead concentration than in the lowest quartile ( $78.4 \%$ vs $79.0 \%$; $P=0.025$ ).

There was no difference in FEV 1 between the lowest quartile $(\leq 0.77 \mu \mathrm{g} / \mathrm{L})$ and highest quartile $(\geq 1.57 \mu \mathrm{g} / \mathrm{L})$ of cadmium concentration. FVC was higher in subjects in the highest quartile than in those in the lowest quartile, but the dose-response relationship was not significant. The $\mathrm{FEV}_{1} /$ FVC ratio was lower in the highest quartile than in the lowest quartile $(78.3 \%$ vs $79.2 \% ; P<0.001)$.

\section{Adjusted estimates of lead and cadmium levels associated with lung function}

Table 3 shows the adjusted estimates of lead and cadmium levels associated with lung function according to multiple linear regression after log-transformation. On adjustment for age, sex, and smoking status, the $\mathrm{FEV}_{1} / \mathrm{FVC}$ ratio decreased with increasing concentrations of lead (estimated -0.002 ; $P=0.007$ ) and cadmium (estimated $-0.005 ; P=0.001$ ). However, blood levels of lead and cadmium were not significantly related to $\mathrm{FEV}_{1}$ or FVC. On stratification for smoking status (never, former, and current), the blood lead level was associated with $\mathrm{FEV}_{1} / \mathrm{FVC}$ only in never smokers (estimated $=-0.003, P=0.007$ ) while the blood cadmium level was associated with $\mathrm{FEV}_{1} / \mathrm{FVC}$ in both former and current smokers (estimated $=-0.011, P=0.016$ and estimated $=-0.008, P=0.002$, respectively).

\section{Baseline characteristics and blood lead and cadmium levels between non-OLF and OLF groups}

Among the 5,972 subjects, 5,298 (88.7\%) was classified as the non-OLF group and $674(11.3 \%)$ as the OLF group. The demographic and clinical characteristics of the study population are shown in Table 4. The OLF group was older than the non-OLF group (59.7 years vs 49.3 years; $P<0.001)$ and contained a higher percentage of males (75.6\% vs $48.0 \% ; P<0.001)$ than the non-OLF group. Moreover, the OLF group contained a higher proportion of ever smokers ( $70.4 \%$ vs $41.8 \% ; P<0.001)$. The mean levels of lead $(2.77 \mu \mathrm{g} / \mathrm{dL}$ vs $2.36 \mu \mathrm{g} / \mathrm{dL} ; P<0.001)$ and cadmium $(1.18 \mu \mathrm{g} / \mathrm{dL}$ vs $1.06 \mu \mathrm{g} / \mathrm{dL} ; P<0.001)$ in the OLF group were higher than in the non-OLF group. Regardless of smoking status, lead levels in the blood were all higher in the OLF group than in the non-OLF group. However, cadmium levels were higher in the OLF group than in the non-OLF group among ever smokers. 
Table 3 Adjusted estimates of blood lead and cadmium levels for lung function according to multiple linear regression

\begin{tabular}{|c|c|c|c|c|c|c|}
\hline \multirow{2}{*}{$\begin{array}{l}\text { Dependent } \\
\text { parameters }\end{array}$} & Estimated & SE & $P$-value & Estimated & SE & $P$-value \\
\hline & \multicolumn{3}{|l|}{ Lead } & \multicolumn{3}{|l|}{ Cadmium } \\
\hline \multicolumn{7}{|l|}{ All* } \\
\hline $\mathrm{FEV}_{1}, \mathrm{~L}$ & -0.000006 & 0.059 & 0.999 & 0.003 & 0.009 & $0.76 \mathrm{I}$ \\
\hline FVC, L & 0.009 & 0.006 & 0.147 & 0.029 & 0.002 & 0.336 \\
\hline $\mathrm{FEV}_{1} / \mathrm{FVC}, \%$ & -0.002 & 0.001 & 0.007 & -0.005 & 0.001 & 0.001 \\
\hline \multicolumn{7}{|l|}{ Never smoker** } \\
\hline $\mathrm{FEV}_{\text {, }} \mathrm{L}$ & 0.0006 & 0.007 & 0.930 & 0.006 & 0.011 & 0.602 \\
\hline FVC, L & 0.012 & 0.009 & 0.164 & 0.017 & 0.013 & 0.197 \\
\hline $\mathrm{FEV}_{1} / \mathrm{FVC}, \%$ & -0.003 & 0.001 & 0.007 & -0.002 & 0.002 & 0.299 \\
\hline \multicolumn{7}{|c|}{ Former smoker** } \\
\hline $\mathrm{FEV}_{1}, \mathrm{~L}$ & -0.0002 & 0.011 & 0.987 & 0.045 & 0.03 & 0.142 \\
\hline FVC, L & 0.0047 & 0.013 & 0.707 & 0.115 & 0.036 & 0.001 \\
\hline $\mathrm{FEV}_{1} / \mathrm{FVC}, \%$ & -0.00078 & 0.002 & 0.623 & -0.011 & 0.005 & 0.016 \\
\hline \multicolumn{7}{|c|}{ Current smoker** } \\
\hline $\mathrm{FEV}_{1}, \mathrm{~L}$ & 0.002 & 0.009 & 0.807 & -0.022 & 0.019 & 0.272 \\
\hline FVC, L & 0.008 & 0.011 & 0.489 & 0.019 & 0.023 & 0.406 \\
\hline $\mathrm{FEV}_{1} / \mathrm{FVC}, \%$ & -0.001 & 0.001 & 0.281 & -0.008 & 0.003 & 0.002 \\
\hline
\end{tabular}

Notes: *Adjusted for age, sex, smoking status (never, former, and current smoker), and body mass index; **adjusted for age, sex, and body mass index.

Abbreviations: $\mathrm{FEV}_{1}$, forced expiratory volume in I second; FVC, forced vital capacity; SE, standard error.

\section{Prevalence and adjusted odds ratio for OLF according to heavy metal category}

Figure 1 demonstrates the prevalence of OLF in the quartile groups according to lead and cadmium levels. We observed that the prevalence of OLF increased among current smokers when lead levels increased $(P=0.004)$, but there was no

Table 4 Baseline characteristics between non-OLF and OLF groups*

\begin{tabular}{|c|c|c|c|}
\hline \multirow{2}{*}{$\begin{array}{l}\text { Baseline } \\
\text { characteristics }\end{array}$} & \multirow{2}{*}{$\begin{array}{l}\text { Non-OLF } \\
(n=5,298)\end{array}$} & \multirow{2}{*}{$\begin{array}{l}\text { OLF } \\
(n=674)\end{array}$} & \multirow[t]{2}{*}{$P$-value } \\
\hline & & & \\
\hline Age, years & $49.3 \pm 12.4$ & $59.7 \pm 1 \mid .8$ & $<0.00$ I \\
\hline Male & $2,545(48.0)$ & $510(75.6)$ & $<0.00$ I \\
\hline $\mathrm{BMI}, \mathrm{kg} / \mathrm{m}^{2}$ & $24.2 \pm 3.0$ & $23.6 \pm 2.9$ & $<0.001$ \\
\hline \multicolumn{4}{|l|}{ Smoking status ${ }^{* *}$} \\
\hline Never smoker & $3,057(58.1)$ & 197 (29.5) & $<0.00$ I \\
\hline Ever smoker & $2,199(41.8)$ & $470(70.4)$ & \\
\hline Former smoker & $990(45.0)$ & $238(50.6)$ & 0.027 \\
\hline Current smoker & $1,209(54.9)$ & $232(49.3)$ & \\
\hline \multicolumn{4}{|l|}{ Lead } \\
\hline Total, $\mu g / d L$ & $2.36(2.33,2.38)$ & $2.77(2.68,2.86)$ & $<0.001$ \\
\hline \multicolumn{4}{|l|}{ Smoking status } \\
\hline Never, $\mu \mathrm{g} / \mathrm{dL}$ & $2.10(2.07,2.13)$ & $2.27(2.13,2.42)$ & 0.014 \\
\hline Former, $\mu \mathrm{g} / \mathrm{dL}$ & $2.72(2.65,2.78)$ & $2.88(2.74,3.04)$ & 0.033 \\
\hline Current, $\mu g / d L$ & $2.81(2.75,2.88)$ & $3.13(2.98,3.28)$ & $<0.00$ I \\
\hline \multicolumn{4}{|l|}{ Cadmium } \\
\hline Total, $\mu \mathrm{g} / \mathrm{dL}$ & $1.06(1.04,10.8)$ & $1.18(1.14,1.23)$ & $<0.001$ \\
\hline \multicolumn{4}{|l|}{ Smoking status } \\
\hline Never, $\mu \mathrm{g} / \mathrm{dL}$ & $1.08(1.06,1.10)$ & $1.09(1.01,1.18)$ & $0.78 I$ \\
\hline Former, $\mu \mathrm{g} / \mathrm{dL}$ & $0.86(0.83,0.89)$ & $1.00(0.94,1.06)$ & $<0.00$ I \\
\hline Current, $\mu \mathrm{g} / \mathrm{dL}$ & $1.21(1.17,1.24)$ & $1.50(1.42,1.59)$ & $<0.001$ \\
\hline
\end{tabular}

Notes: *Data are presented as numbers (percentages), and plus-minus values are the mean \pm standard deviation unless otherwise indicated; **data of smoking status were not available in 18 subjects in the non-OLF group and in two subjects in the OLF group.

Abbreviations: OLF, obstructive lung function; BMI, body mass index. significant dose-response relationship in former and never smokers. The prevalence of OLF increased among former and current smokers when cadmium levels increased $(P<0.004)$, but there was no significant dose-response relationship in never smokers.

Figure 2 demonstrates the odds ratios and $95 \%$ confidence intervals for the prevalence of OLF in the quartile groups compared to the reference group of the lowest quartile according to lead and cadmium levels. The odds ratio was evaluated after adjustment for age, sex, and BMI. There was no significant association between the prevalence of OLF and lead concentrations in never, former, or current smokers. However, the risk for OLF was significantly higher for subjects in the highest quartile of cadmium concentration (odds ratio 1.94; 95\% confidence interval 1.06-3.57) than for those in the lowest quartile among current smokers.

\section{Discussion}

In this study, we demonstrated a significant association between the $\mathrm{FEV}_{1} / \mathrm{FVC}$ ratio and lead and cadmium levels in the blood in a large nationally representative sample of the Korean population. Upon adjusted analysis, the $\mathrm{FEV}_{1} /$ FVC ratio decreased as the blood concentrations of lead and cadmium increased. We also evaluated the relationship of OLF with lead and cadmium levels. The OLF group had higher levels of lead and cadmium than the non-OLF group and the prevalence of OLF increased as the level of lead and cadmium increased, especially among current smokers. According to adjusted analysis, the risk of OLF was higher in 

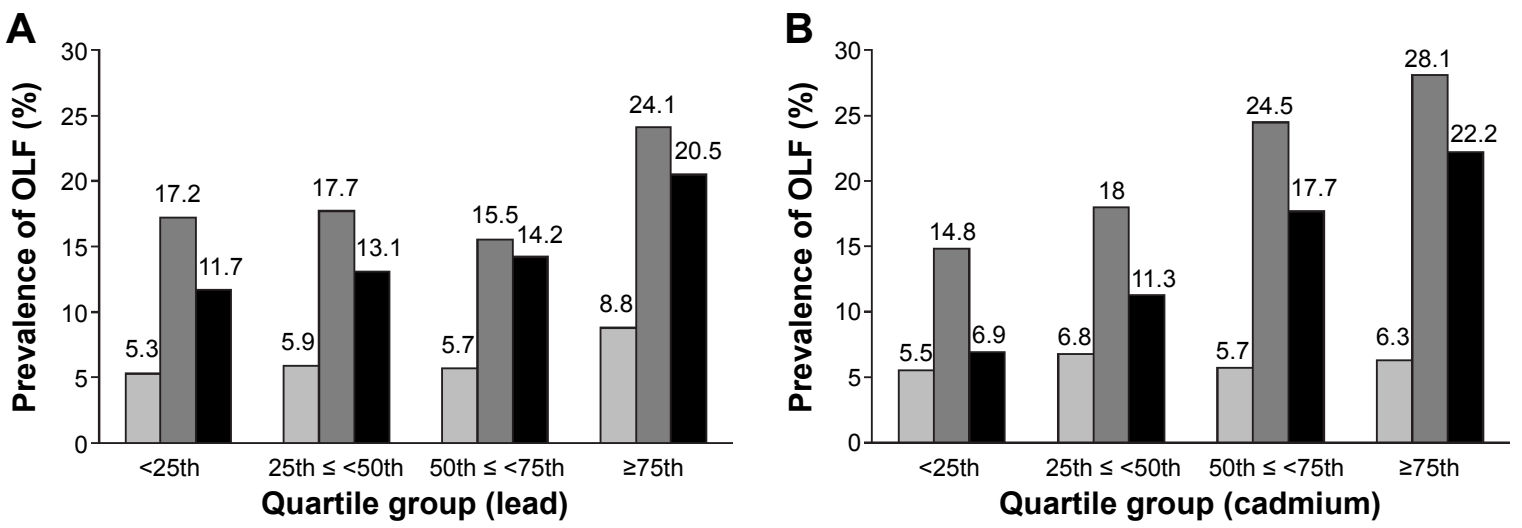

Figure I Prevalence of OLF in quartile groups according to blood levels of lead and cadmium.

Notes: (A) Proportion of OLF in never smokers in each quartile group (lead) was $5.3 \%, 5.9 \%, 5.7 \%$, and $8.8 \%(P=0.058)$; $17.2 \%, 17.7 \%$, $15.5 \%$, and $24.1 \%$ in former smokers $(P=0.014)$; and $11.7 \%, 13.1 \%, 14.2 \%$, and $20.5 \%$ in current smokers ( $P=0.004)$. (B) Proportion of OLF in never smokers in each quartile group (cadmium) was $5.5 \%, 6.8 \%, 5.7 \%$, and 6.3\% $(P=0.666) ; 14.8 \%, 18.0 \%, 24.5 \%$, and $28.1 \%$ in former smokers $(P<0.001)$; and $6.9 \%, 11.3 \%, 17.7 \%$, and $22.2 \%$ in current smokers $(P<0.001)$. Gray, never smoker; dark gray, former smoker; black, current smoker.

Abbreviation: OLF, obstructive lung function.

subjects with cadmium concentrations in the highest quartile when compared with those with the lowest quartile among current smokers.

Although the levels of lead and cadmium were associated with the $\mathrm{FEV}_{1} / \mathrm{FVC}$ ratio and prevalence of OLF, overall levels of heavy metals in the blood were lower than those stated by current safety standards. ${ }^{18}$ For both lead and cadmium, blood levels of $5 \mu \mathrm{g} / \mathrm{dL}$ or higher are considered to increase the risk of adverse systemic health effects. ${ }^{19,20}$

Recently, Rokadia and Agarwal reported a significant relationship between heavy metal exposure based on blood levels of lead and cadmium and obstructive lung disease in a
A

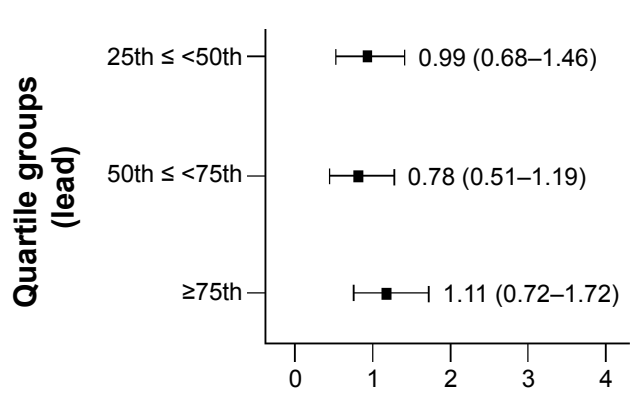

B

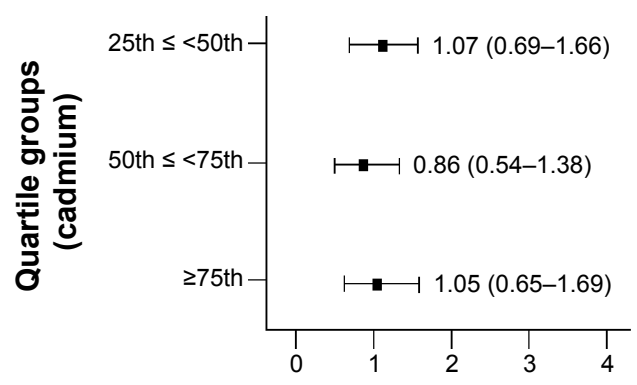

Former smoker

$\mapsto 0.93(0.53-1.63)$

$\mapsto-10.76(0.44-1.31)$

$\longmapsto 1.28(0.78-2.12)$

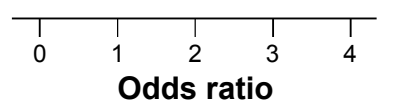

Former smoker

$\mapsto-10.92(0.61-1.37)$

$\longmapsto 1.33(0.86-2.04)$

$\longmapsto 1.27(0.77-2.10)$

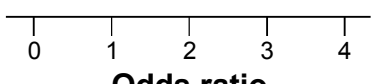

Odds ratio
Current smoker
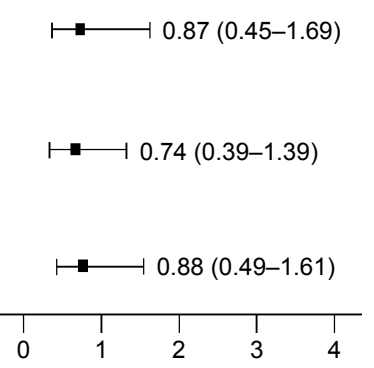

Current smoker

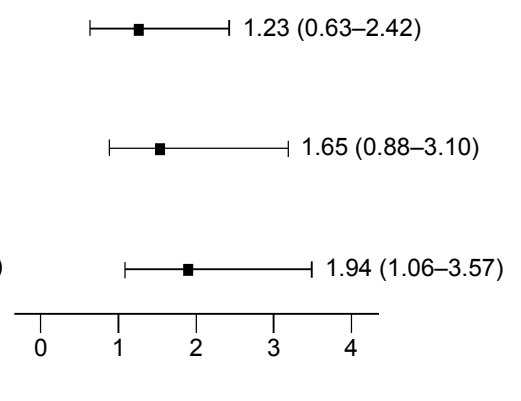

Figure 2 Odds ratio for OLF according to blood levels of lead and cadmium stratified by smoking status.

Notes: Adjusted odds ratios and $95 \%$ confidence intervals $(\mathrm{Cl})$ of the prevalence of obstructive lung disease in the quartile groups stratified by smoking status compared with the reference group of the lowest quartile (group I). All regression models were adjusted for age, sex, and body mass index. (A) Lead and (B) cadmium.

Abbreviation: OLF, obstructive lung function. 
large representative sample in the USA. ${ }^{10}$ The risk of obstructive lung disease was elevated with increased concentrations of lead and cadmium. A dose-response effect between increasing cadmium concentration and progressively worsening lung function $\left(\mathrm{FEV}_{1} \%\right.$ predicted) was observed only in smokers. However, a dose-dependent inverse association between increasing lead concentration and worsening lung function ( $\mathrm{FEV}_{1}$ \%predicted) was observed in both smokers and never smokers. They suggested that cadmium may mediate the association between smoking and obstructive lung disease. ${ }^{10}$

Our study also analyzed the relationship of blood lead and cadmium levels with lung function and prevalence of OLF. Compared with the study of Rokadia and Agarwal our study showed a higher level of lead and a lower level of cadmium in blood. A higher proportion of subjects in their study were current smokers, which could be one of the reasons for the higher blood level of cadmium. Moreover, as the food chain is a major route of lead exposure, a higher level of cadmium may be related to boiled rice, which is a staple food in Korea. ${ }^{21}$ Particulate matter $(\mathrm{PM})_{10}$ is one of the sources of heavy metals. Over $53 \%$ of $\mathrm{PM}_{10}$ in South Korea is estimated to be emitted from the vehicles with diesel engines. ${ }^{22}$ According to the study reported by Kim et al the average daily concentrations of $\mathrm{PM}_{10}$ in the seven Korean cities were similar to that described in the World Health Organization Global Guidelines for ambient air quality. ${ }^{21}$

We included not only the $\mathrm{FEV}_{1}$, but also the $\mathrm{FEV}_{1} / \mathrm{FVC}$ ratio as indicators of airway obstruction. Although we failed to demonstrate a relationship between $\mathrm{FEV}_{1}$ and blood heavy metal levels, the $\mathrm{FEV}_{1} / \mathrm{FVC}$ ratio decreased with increasing concentrations of lead levels in never smokers and cadmium levels in ever smokers. A different distribution of blood lead and cadmium levels would contribute to the different relationship between blood heavy metal levels and lung function parameters when compared with Rokadia and Agarwal. Among ever smokers, the risk of OLF was elevated with increased concentrations of cadmium only. In the case of lead, the difference was not statistically significant between the different concentration quartiles regardless of smoking status. Therefore, this study also supports the previous report that cadmium may be associated with smoking-related risks of OLF.

Cadmium can enter humans via ingestion or inhalation. Ingestion is a major source of exposure in the general nonsmoking population, whereas inhalation exposure is primarily seen in smokers. ${ }^{8,11}$ Cigarette smoking is a major source of cadmium exposure and increases the level of cadmium in the blood of smokers as much as four to five times that in non-smokers. ${ }^{24}$ Chronic exposure to cadmium leads to renal glomerular and tubular damage, disorders of calcium and bone metabolism, malignancy, and cardiovascular and respiratory disease. ${ }^{25}$ The mechanisms of the toxicity of heavy metals in the lung are still unclear. However, the induction of oxidative stress, disruption of barrier mechanisms and the extracellular matrix, and possible impaired DNA repair and apoptosis were considered to be related to the mechanism of cadmium toxicity in the lung according to the experimental models. ${ }^{23,26-29}$ Cadmium directly affects adherence junction proteins, resulting in barrier function disruption, disorganizes the collagen cross-linking and elastin stabilizing the extracellular matrix, and accelerates collagen and elastin damage leading to emphysema. ${ }^{23,29} \mathrm{Cadmium}$ also generates reactive oxygen species and induces impaired DNA repair and apoptosis. ${ }^{26,28,30-32}$

Among never smokers, occupational cadmium exposure has been considered a risk factor for the development of OLF. ${ }^{4}$ Increased urinary cadmium was associated with worse lung function and smoking-related emphysema. ${ }^{8,33}$ These negative effects are due to low excretion rate (a half-life as long as 15-20 years) of cadmium and its tendency for accumulation. ${ }^{34}$

Lead intake in humans occurs through ingestion, inhalation, and the skin. Airborne lead is deposited in soil and water. Thus, human exposure to lead occurs through the food chain and drinking water, which is the major exposure pathway for the general non-smoking adult population. Lead exposure through inhalation in the form of dust or vapor depends on several factors, such as occupation, tobacco use, and leisure activities. ${ }^{9,12}$ Cigarettes contain nearly $2.4 \mu \mathrm{g} / \mathrm{g}$ of lead, of which $5 \%$ is inhaled and the remainder is found in the ash and side stream smoke. ${ }^{12,35}$ Although the respiratory system is one of the main routes of entry for lead, there are a limited number of studies regarding the effect of lead on the lungs, and most of these studies described the impact of lead on the hematopoietic, cardiovascular, reproductive, and nervous systems, as well as on renal disease. ${ }^{36,37}$ Lymphocyte and monocyte infiltration and collagen accumulation were evident in the interalveolar septa in the lung tissues of rats exposed to lead. ${ }^{38}$ Risk for lung cancer was reported among lead smelter workers in a lead cohort study. ${ }^{39}$ Pulmonary function was worse in battery and exhaust workers, who showed higher blood levels of lead than the controls. ${ }^{9}$ Likewise, we also found that the $\mathrm{FEV}_{1} / \mathrm{FVC}$ ratio was worse as the blood lead levels increased. 
This study has several limitations. First, it was a crosssectional observational study, so it is difficult to clarify the cause-and-effect relationship between cadmium and lead levels and lung function. Second, questions related to occupational exposure to lead or cadmium were not specifically asked, and data regarding dietary intake and amount of smoking were not considered in the analysis. However, the aim of this study was to investigate the relationship between heavy metal levels in the blood and lung function regardless of exposure and dietary intake. Subjects who are exposed to heavy metals through occupation, high dietary intake, and large amounts of smoking would likely show high levels of heavy metals in the blood. Lastly, the blood lead and cadmium levels were generally in the normal range because most participants in KNHANES are probably not exposed to an environment that is extremely contaminated with such chemicals. Therefore, there would be a limit to our ability to demonstrate a relationship between abnormally high blood levels of heavy metals and lung function.

\section{Conclusion}

In conclusion, we demonstrated a significant association between $\mathrm{FEV}_{1} / \mathrm{FVC}$ ratio and blood concentrations of lead and cadmium in the general Korean population. The OLF group had higher blood levels of lead and cadmium than the non-OLF group. The risk for OLF was elevated with increased concentrations of cadmium, especially among smokers. However, additional research with more etiologies is needed to elucidate the association between heavy metals and lung function.

\section{Acknowledgments}

We thank the Korea Centers for Disease Control and Prevention for providing the data from the Korea National Health and Nutrition Examination Survey. This study was supported by a new faculty research seed money grant from Yonsei University College of Medicine for 2013 (2013-32-0014).

\section{Disclosure}

The authors report no conflicts of interest in this work.

\section{References}

1. Snider GL. Chronic obstructive pulmonary disease: risk factors, pathophysiology and pathogenesis. Annu Rev Med. 1989;40:411-429.

2. Bridevaux PO, Probst-Hensch NM, Schindler C, et al. Prevalence of airflow obstruction in smokers and never-smokers in Switzerland. Eur Respir J. 2010;36(6):1259-1269.

3. Kim DS, Kim YS, Jung KS, et al. Prevalence of chronic obstructive pulmonary disease in Korea: a population-based spirometry survey. Am J Respir Crit Care Med. 2005;172(7):842-847.
4. Balmes J, Becklake M, Blanc P, et al. American Thoracic Society Statement: Occupational contribution to the burden of airway disease. Am J Respir Crit Care Med. 2003;167(5):787-797.

5. Sunyer J. Urban air pollution and chronic obstructive pulmonary disease: a review. Eur Respir J. 2001;17(5):1024-1033.

6. Kirschvink N, Martin N, Fievez L, Smith N, Marlin D, Gustin P. Airway inflammation in cadmium-exposed rats is associated with pulmonary oxidative stress and emphysema. Free Radic Res. 2006;40(3): 241-250.

7. Armstrong BG, Kazantzis G. The mortality of cadmium workers. Lancet. 1983;1(8339):1425-1427.

8. Mannino DM, Holguin F, Greves HM, Savage-Brown A, Stock AL, Jones RL. Urinary cadmium levels predict lower lung function in current and former smokers: data from the Third National Health and Nutrition Examination Survey. Thorax. 2004;59(3):194-198.

9. Bagci C, Bozkurt AI, Cakmak EA, Can S, Cengiz B. Blood lead levels of the battery and exhaust workers and their pulmonary function tests. Int J Clin Pract. 2004;58(6):568-572.

10. Rokadia H, Agarwal S. Serum heavy metals and obstructive lung disease: results from the National Health and Nutrition Examination Survey. Chest. 2013;143(2):388-397.

11. Jarup L. Hazards of heavy metal contamination. Br Med Bull. 2003;68:167-182.

12. International Programme on Chemical Safety. Environmental health criteria for inorganic lead. Available from: http://www.inchem.org/ documents/ehc/ehc/ehc165.htm. Accessed November 13, 2013.

13. Chung S, Chung JH, Kim SJ, et al. Blood lead and cadmium levels and renal function in Korean adults. Clin Exp Nephrol. 2014;18(5): 726-734.

14. Moon SS. Association of lead, mercury and cadmium with diabetes in the Korean population: the Korea National Health and Nutrition Examination Survey (KNHANES) 2009-2010. Diabet Med. 2013;30(4):e143-e148.

15. Korea Centers for Disease Control and Prevention. KNHANE - Korea National Health and Nutrition Examination Survey. Available from: http://knhanes.cdc.go.kr/. Accessed May 5, 2013.

16. American Thoracic Society. Standardization of spirometry, 1994 update. Am J Respir Crit Care Med. 1995;152(3):1107-1136.

17. Global Initiative for Chronic Obstructive Lung Disease. Global strategy for the diagnosis, management, and prevention of chronic obstructive pulmonary disease (updated 2013). Available from: http://www. goldcopd.org/uploads/users/files/GOLD_Report_2013_Feb20.pdf. Accessed October 11, 2013.

18. [No authors listed]. Adult blood lead epidemiology and surveillanceUnited States, 2008-2009. MMWR Morb Mortal Wkly Rep. 2011; 60(25):841-845.

19. Kosnett MJ, Wedeen RP, Rothenberg SJ, et al. Recommendations for medical management of adult lead exposure. Environ Health Perspect. 2007;115(3):463-471.

20. Occupational Safety and Health Administration. Cadmium. Available from: https://www.osha.gov/Publications/3136-08R-2003-English. html\#contents. Accessed December 19, 2013.

21. Moon CS, Paik JM, Choi CS, Kim DH, Ikeda M. Lead and cadmium levels in daily foods, blood and urine in children and their mothers in Korea. Int Arch Occup Environ Health. 2003;76(4):282-288.

22. National Institute of Environmental Research. [National Air Pollutant Emission 2010]. Incheon, South Korea: National Institute of Environmental Research; 2012. Korean.

23. Forti E, Bulgheroni A, Cetin Y, et al. Characterisation of cadmium chloride induced molecular and functional alterations in airway epithelial cells. Cell Physiol Biochem. 2010;25(1):159-168.

24. Jarup L, Berglund M, Elinder CG, Nordberg G, Vahter M. Health effects of cadmium exposure - a review of the literature and a risk estimate. Scand J Work Environ Health. 1998;24 Suppl 1:1-51.

25. International Programme on Chemical Safety. Environmental health criteria for cadmium. Available from: http://www.inchem.org/documents/ ehc/ehc/ehc134.htm. Accessed November 13, 2013. 
26. Gong Q, Hart BA. Effect of thiols on cadmium-induced expression of metallothionein and other oxidant stress genes in rat lung epithelial cells. Toxicology. 1997;119(3):179-191.

27. Croute F, Beau B, Arrabit C, et al. Pattern of stress protein expression in human lung cell-line A549 after short- or long-term exposure to cadmium. Environ Health Perspect. 2000;108(1):55-60.

28. Souza V, Escobar Md Mdel C, Gomez-Quiroz L, et al. Acute cadmium exposure enhances AP-1 DNA binding and induces cytokines expression and heat shock protein 70 in HepG2 cells. Toxicology. 2004;197(3):213-228.

29. Zhao Y, Gao S, Chou IN, Toselli P, Stone P, Li W. Inhibition of the expression of lysyl oxidase and its substrates in cadmium-resistant rat fetal lung fibroblasts. Toxicol Sci. 2006;90(2):478-489.

30. Valko M, Rhodes CJ, Moncol J, Izakovic M, Mazur M. Free radicals, metals and antioxidants in oxidative stress-induced cancer. Chem Biol Interact. 2006;160(1):1-40.

31. Liu J, Qu W, Kadiiska MB. Role of oxidative stress in cadmium toxicity and carcinogenesis. Toxicol Appl Pharmacol. 2009;238(3):209-214.

32. Koizumi S, Gong P, Suzuki K, Murata M. Cadmium-responsive element of the human heme oxygenase-1 gene mediates heat shock factor 1-dependent transcriptional activation. J Biol Chem. 2007;282(12): 8715-8723.
33. Davison AG, Fayers PM, Taylor AJ, et al. Cadmium fume inhalation and emphysema. Lancet. 1988;1(8587):663-667.

34. Bertin G, Averbeck D. Cadmium: cellular effects, modifications of biomolecules, modulation of DNA repair and genotoxic consequences (a review). Biochimie. 2006;88(11):1549-1559.

35. Mussalo-Rauhamaa H, Leppanen A, Salmela SS, Pyysalo H. Cigarettes as a source of some trace and heavy metals and pesticides in man. Arch Environ Health. 1986;41(1):49-55.

36. Bellinger DC. The protean toxicities of lead: new chapters in a familiar story. Int J Environ Res Public Health. 2011;8(7):2593-2628.

37. Landrigan PJ. Current issues in the epidemiology and toxicology of occupational exposure to lead. Environ Health Perspect. 1990;89:61-66.

38. Onarlioglu B, Onarlioglu T, Erdal S. The effect of lead inhalation on rat lung morphology. Turk J Med Sci. 1999;29:617-622.

39. Englyst V, Lundstrom NG, Gerhardsson L, Rylander L, Nordberg G. Lung cancer risks among lead smelter workers also exposed to arsenic. Sci Total Environ. 2001;273(1-3):77-82. 


\section{Supplementary materials}

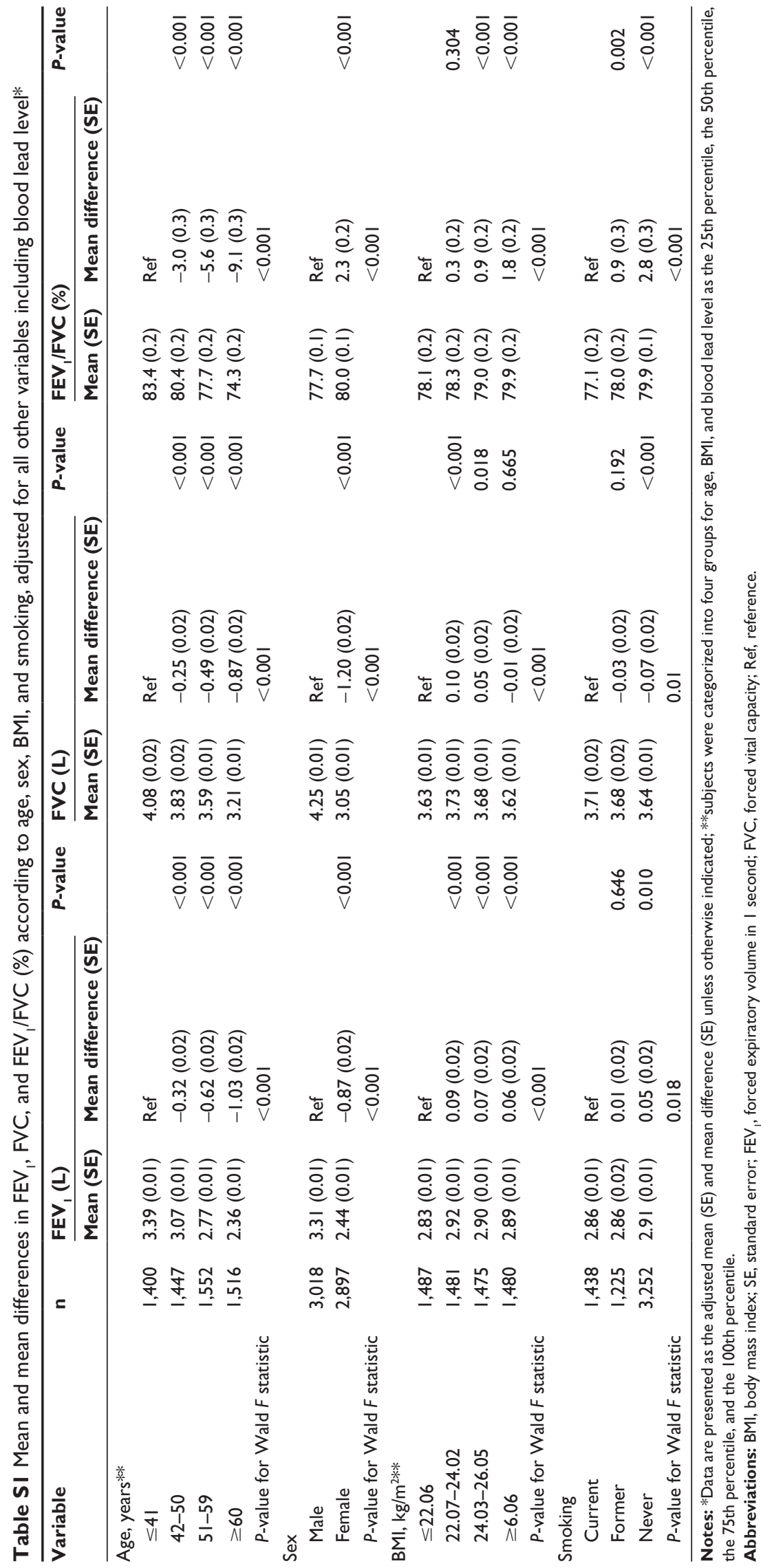




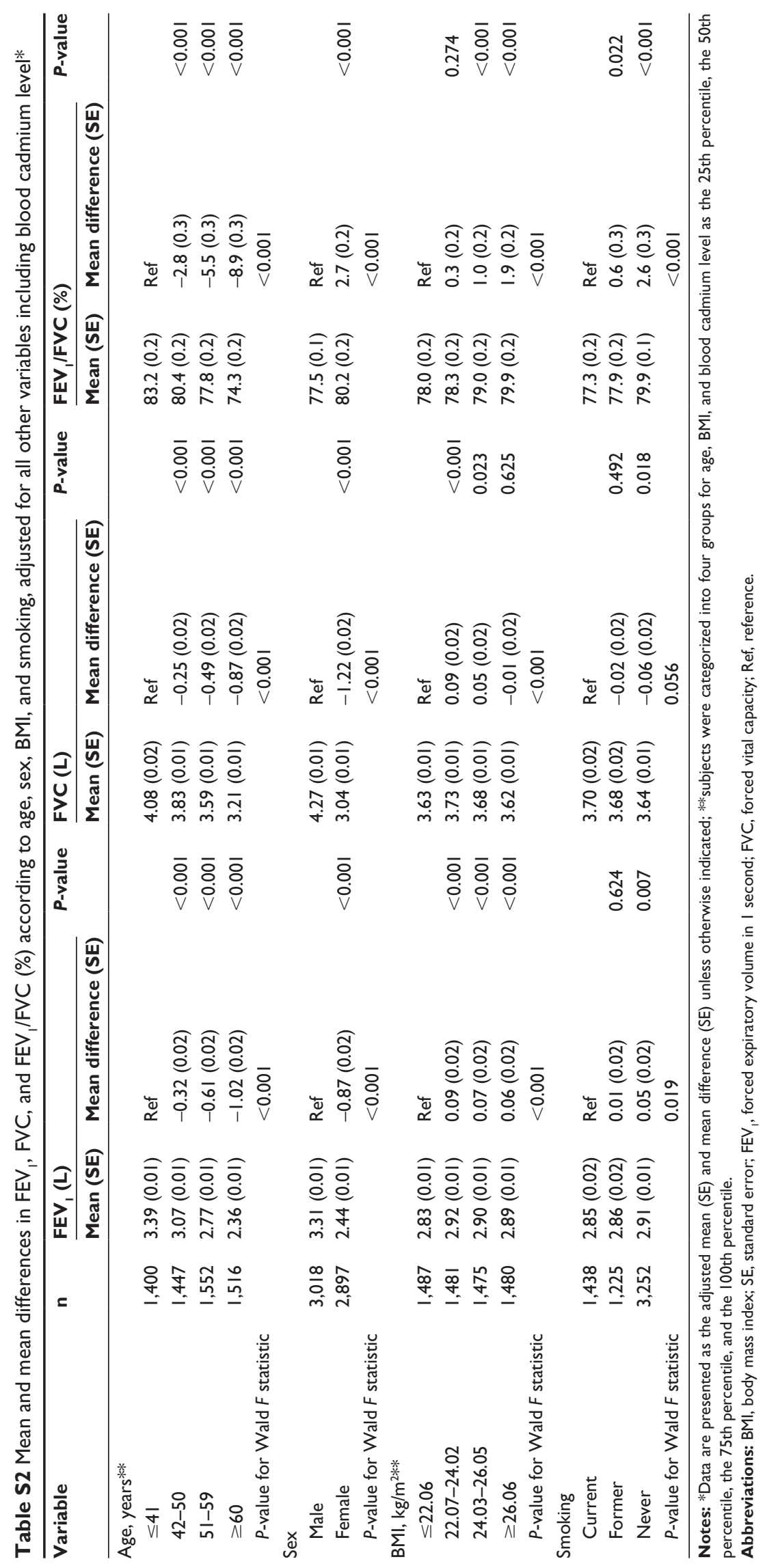




\section{Publish your work in this journal}

The International Journal of COPD is an international, peer-reviewed journal of therapeutics and pharmacology focusing on concise rapid reporting of clinical studies and reviews in COPD. Special focus is given to the pathophysiological processes underlying the disease, intervention programs, patient focused education, and self management protocols.

This journal is indexed on PubMed Central, MedLine and CAS. The manuscript management system is completely online and includes a very quick and fair peer-review system, which is all easy to use. Visit http://www.dovepress.com/testimonials.php to read real quotes from published authors.

Submit your manuscript here: http://www.dovepress.com/international-journal-of-chronic-obstructive-pulmonary-disease-journal 